\title{
Pseudoteredinibacter isoporae gen. nov., sp. nov., a marine bacterium isolated from the reef-building coral Isopora palifera
}

\author{
Ming-Hui Chen, ${ }^{1}$ Shih-Yi Sheu, ${ }^{2}$ A. B. Arun, ${ }^{3}$ Chiu-Chung Young, ${ }^{4}$ \\ Chaolun Allen Chen, ${ }^{5}$ Jih-Terng Wang ${ }^{6}$ and Wen-Ming Chen ${ }^{1}$ \\ ${ }^{1}$ Laboratory of Microbiology, Department of Seafood Science, National Kaohsiung Marine \\ University, No. 142, Hai-Chuan Rd, Nan-Tzu, Kaohsiung City 811, Taiwan \\ ${ }^{2}$ Department of Marine Biotechnology, National Kaohsiung Marine University, Kaohsiung, Taiwan \\ ${ }^{3}$ Yenepoya Research Center, Yenepoya University, Deralakatee, Mangalore, Karnataka, India \\ ${ }^{4}$ Department of Soil Environmental Science, College of Agriculture and Natural Resources, National \\ Chung Hsing University, Taichung, Taiwan \\ ${ }^{5}$ Research Center for Biodiversity, Academia Sinica, Nangang 115, Taipei, Taiwan \\ ${ }^{6}$ Institute of Biotechnology, Tajen University, Yanpu, Pingtung 907, Taiwan
}

Correspondence

Wen-Ming Chen p62365@ms28.hinet.net
Corals harbour a diverse array of bacterial associates (reviewed by Brown \& Bythell, 2005), some of which are thought to be site- and species-specific (Hong et al., 2009; Chiou et al., 2010; Kvennefors et al., 2010). Coralassociated bacteria are increasingly considered to be important in coral health, and altered bacterial community structures have been linked to both coral disease and

The GenBank/EMBL/DDBJ accession number for the $16 \mathrm{~S}$ rRNA gene sequence of strain $\mathrm{SW}-11^{\top}$ is FJ347760.

Four supplementary figures are available with the online version of this paper. bleaching (Rosenberg et al., 2007; Sampayo et al., 2008; Rypien et al., 2010). Recent research indicates that, although site-specific variations in the bacterial communities of healthy corals are present, host species-specific bacterial associates within a distinct cluster of gammaproteobacteria can be identified that are potentially linked to coral health (Kvennefors et al., 2010). It is important to understand the dynamics of the coral-associated bacterial community structures of healthy and unhealthy corals.

During screening for novel micro-organisms from a coral of the species Isopora palifera at Kenting, Taiwan (GPS location: $21^{\circ} 52^{\prime} 35^{\prime \prime} \mathrm{N} 120^{\circ} 43^{\prime} 29^{\prime \prime} \mathrm{E}$ ), several different 
isolates were obtained. This study is focused on one isolate, SW- $11^{\mathrm{T}}$. Comparative $16 \mathrm{~S}$ rRNA gene sequence analysis indicated that strain $\mathrm{SW}-11^{\mathrm{T}}$ forms an independent branch within the Gammaproteobacteria. Accordingly, the aim of the present work was to determine the exact taxonomic position of strain $\mathrm{SW}-11^{\mathrm{T}}$ by a polyphasic characterization that included phenotypic and chemotaxonomic properties and detailed phylogenetic analysis based on 16S rRNA gene sequences.

Strain $\mathrm{SW}-11^{\mathrm{T}}$ was isolated and maintained on marine 2216 agar (MA; BD Difco) or in marine 2216 broth (MB; BD Difco) and formed semi-translucent colonies after incubation at $30{ }^{\circ} \mathrm{C}$ for 2 days. Subcultivation was done on MA at $30{ }^{\circ} \mathrm{C}$ for $24-48 \mathrm{~h}$. On this medium, strain SW $-11^{\mathrm{T}}$ was able to grow at $10-45{ }^{\circ} \mathrm{C}$ but not at 4 or $50{ }^{\circ} \mathrm{C}$. The strain was preserved at $-80{ }^{\circ} \mathrm{C}$ as a $20 \%(\mathrm{v} / \mathrm{v})$ glycerol suspension in $\mathrm{MB}$ or by lyophilization with $20 \%$ (w/v) skimmed milk. Saccharophagus degradans DSM $17024^{\mathrm{T}}$ and Teredinibacter turnerae ATCC $39867^{\mathrm{T}}$ were obtained from the Deutsche Sammlung von Mikroorganismen und Zellkulturen (DSMZ) and the American Type Culture Collection (ATCC), respectively, and used as reference strains for both phenotypic and genotypic tests. S. degradans DSM $17024^{\mathrm{T}}$ was grown and maintained on MA. T. turnerae ATCC $39867^{\mathrm{T}}$ was grown and maintained on shipworm basal medium (SBM), as described previously (Waterbury et al., 1983; Distel et al., 2002).

The 16S rRNA gene sequence of strain $\mathrm{SW}-11^{\mathrm{T}}$ was determined and analysed as described previously (Chen et al., 2001). Analysis of the sequence was performed by using the software package BioEdit (Hall, 1999) and MEGA version 3.1 (Kumar et al., 2004), after multiple alignments by using CLUSTAL_X (Thompson et al., 1997). The distance matrix method was employed (distance options according to Kimura's two-parameter model; Kimura, 1983), including clustering by the neighbour-joining (Saitou \& Nei, 1987) (Fig. 1), maximum-likelihood (Felsenstein, 1981) and discrete character-based maximum-parsimony (Kluge \& Farris, 1969) methods. In each case, bootstrap values were calculated based on 1000 replications. The $16 \mathrm{~S}$ rRNA gene sequence of strain $\mathrm{SW}-11^{\mathrm{T}}$ was a continuous stretch of $1406 \mathrm{bp}$; analysis indicated that strain $\mathrm{SW}-11^{\mathrm{T}}$ belonged to the class Gammaproteobacteria and was a member of the order Alteromonadales. Sequence similarity calculations using BioEdit software (over $1400 \mathrm{bp}$ ) indicated that strain SW- $-11^{\mathrm{T}}$ was most closely related to T. turnerae $\mathrm{T} 7902^{\mathrm{T}}$ (93.2\% gene sequence similarity) and $S$. degradans $2-40^{\mathrm{T}}$ $(92.1 \%)$. Lower sequence similarities $(<92 \%)$ were found with representatives of other related genera shown in Fig. 1. The overall topologies of the phylogenetic trees obtained with the neighbour-joining, maximum-likelihood and maximum-parsimony methods were similar (Fig. 1 and Supplementary Figs. S1 and S2, available in IJSEM Online).

The morphology of the cells was observed by phasecontrast microscopy (Leica DM 2000) and scanning electron microscopy (S-3500N; Hitachi) (Supplementary Fig. S3) using cells grown in $\mathrm{MB}$ at $30{ }^{\circ} \mathrm{C}$ for $6 \mathrm{~h}$ (lag growth phase), $18 \mathrm{~h}$ (exponential phase) and $36 \mathrm{~h}$ (stationary phase). Motility was tested by the hanging drop method. Flagellar staining was performed using the Spot Test flagella stain (BD Difco). The Gram reaction was tested using the BD Difco Gram stain set and the Ryu nonstaining $\mathrm{KOH}$ method (Powers, 1995). Accumulation of poly- $\beta$-hydroxybutyrate granules was tested by light microscopy after staining cells with Sudan black. Colony morphology was examined using a stereoscopic microscope (SMZ 800; Nikon). Details of cell morphology are given in the species description. The $\mathrm{pH}$ range for growth

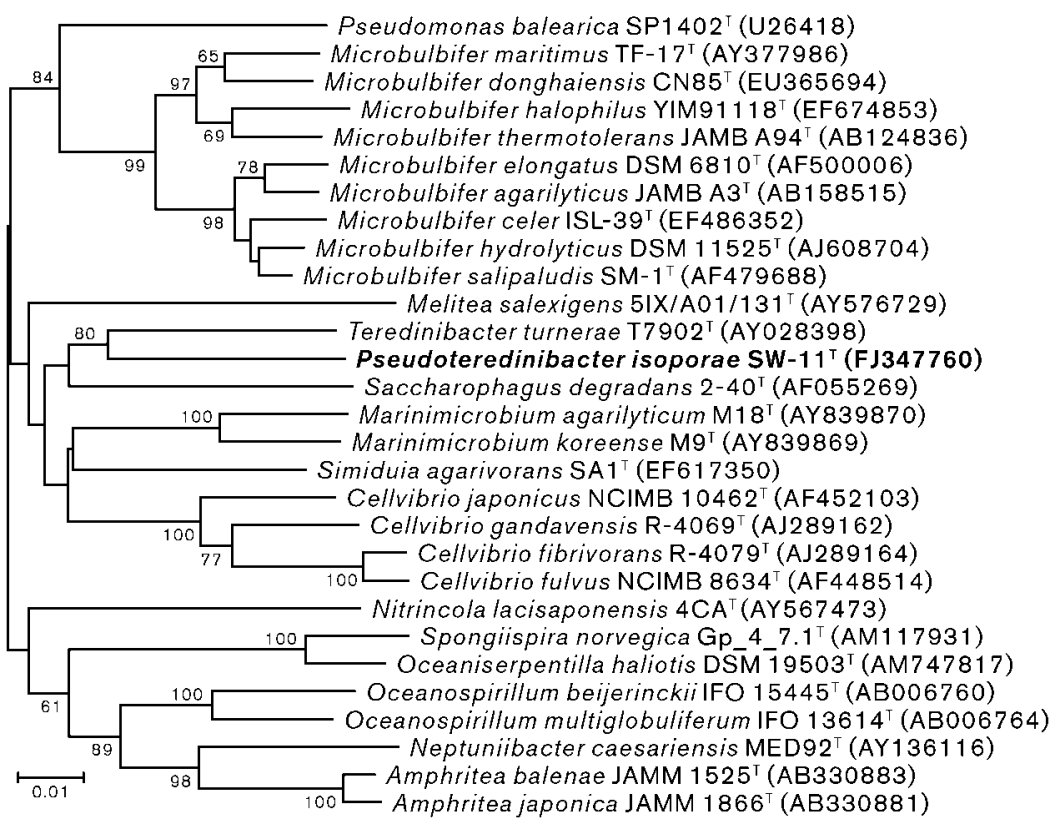

Fig. 1. Neighbour-joining tree based on $16 \mathrm{~S}$ rRNA gene sequences showing the phylogenetic relationships between strain $\mathrm{SW}-11^{\top}$ and some representatives of the class Gammaproteobacteria. Bootstrap values (>50\%) based on 1000 replications are shown at branching points. Bar, 0.01 substitutions per nucleotide position. 
was determined in $\mathrm{R} 2 \mathrm{~A}$ broth medium dissolved in artificial seawater $\left(\mathrm{NaCl}, 24 \mathrm{~g} ; \mathrm{MgCl}_{2}, 5.1 \mathrm{~g} ; \mathrm{Na}_{2} \mathrm{SO}_{4}, 4 \mathrm{~g}\right.$; $\mathrm{CaCl}_{2}, 1.1 \mathrm{~g} ; \mathrm{KCl}, 0.7 \mathrm{~g} ; \mathrm{NaHCO}_{3}, 0.2 \mathrm{~g} ; \mathrm{KBr}, 0.1 \mathrm{~g}$; $\mathrm{H}_{3} \mathrm{BO}_{3}, 0.027 \mathrm{~g} ; \mathrm{SrCl}_{2}, 0.024 \mathrm{~g} ; \mathrm{NaF}, 0.003 \mathrm{~g}$; distilled water to $1 \mathrm{l}$; Lyman \& Fleming, 1940) using appropriate biological buffers (glycine/HCl, citrate $/ \mathrm{Na}_{2} \mathrm{HPO}_{4}$, phosphate buffer and glycine $/ \mathrm{NaOH}$ to adjust the $\mathrm{pH}$ to 3.0 $4.0,4.0-8.0,6.0-8.0$ and 9.0-11.0, respectively, at $0.5 \mathrm{pH}$ unit intervals). The $\mathrm{pH}$ was adjusted prior to sterilization, and post-sterilization controls revealed only minor changes. The $\mathrm{NaCl}$ requirement was determined using R2A broth medium containing $0-15.0 \%$ (w/v) $\mathrm{NaCl}$ (at $0.5 \%$ intervals). The temperature for growth was examined at $4,10,15,20,25,30,35,37,40,45$ and $50{ }^{\circ} \mathrm{C}$. Growth was determined by measuring turbidity $\left(\mathrm{OD}_{600}\right)$. Anaerobic growth was assessed using the Oxoid AnaeroGen system (Miller et al., 1995).

Catalase, oxidase, DNase and lipase (corn oil) activities and hydrolysis of starch, casein, agar, gelatin and Tweens 20, 40, 60 and 80 were determined using standard methods (Gerhardt et al., 1994). Hydrolysis of chitin was tested using agar medium supplemented with $0.2 \%$ colloidal chitin (Hsu \& Lockwood, 1975). Colloidal chitin was prepared according to the description of Monreal \& Reese (1969). Hydrolysis of alginate [1\% (w/v) sodium alginate] was examined according to the description of Hosoya et al. (2009) and lecithin hydrolysis was tested by the method of Smibert \& Krieg (1994). Hydrolysis of CM-cellulose was tested as described by Bowman (2000) using R2A medium dissolved in artificial seawater as the basal medium. Eumelanin production via tyrosinase activity was tested according to Kelly et al. (1990). Carbon utilization was tested on basal agar medium supplemented with yeast extract $\left(\mathrm{NaCl}, 23.6 \mathrm{~g} ; \mathrm{KCl}, 0.64 \mathrm{~g} ; \mathrm{MgCl}_{2} .6 \mathrm{H}_{2} \mathrm{O}, 4.53 \mathrm{~g}\right.$; $\mathrm{MgSO}_{4} .7 \mathrm{H}_{2} \mathrm{O}, 5.94 \mathrm{~g} ; \mathrm{CaCl}_{2} .2 \mathrm{H}_{2} \mathrm{O}, 1.3 \mathrm{~g} ; \mathrm{NaNO}_{3}, 0.2 \mathrm{~g}$; $\mathrm{NH}_{4} \mathrm{Cl}, 0.2 \mathrm{~g}$; Bacto agar, $15 \mathrm{~g}$; yeast extract, $0.05 \mathrm{~g}$; distilled water to $1 \mathrm{l}$; Choi et al., 2006) containing $0.2 \%$ of the carbon source. Incubation was prolonged for a month and growth was scored as positive when visible colonies were observed. The API 20NE, API ZYM (bioMérieux) and MicroPlate GN2 (Biolog) microtest systems were used to determine biochemical properties, enzyme activities and carbohydrate utilization. API ZYM tests were performed according to the manufacturer's recommendation and the API ZYM strip was read after $4 \mathrm{~h}$ of incubation at $30{ }^{\circ} \mathrm{C}$. Because strain SW- $11^{\mathrm{T}}$ required $2-$ $3 \% \mathrm{NaCl}$ for optimum growth, the sample was suspended in saline solution $(3 \% \mathrm{NaCl})$ for API $20 \mathrm{NE}$ and MicroPlate GN2 tests. The results were read after $72 \mathrm{~h}$ at $30{ }^{\circ} \mathrm{C}$.

Strain SW- $11^{\mathrm{T}}$ was grown in R2A broth medium dissolved in artificial seawater at $30{ }^{\circ} \mathrm{C}$ for 2 days and isoprenoid quinones were extracted and separated as described by Minnikin et al. (1984) and analysed by HPLC as described by Collins (1985). The major isoprenoid quinones of strain SW- $11^{\mathrm{T}}$ were ubiquinone $9(78.8 \%)$ and ubiquinone 8 $(21.1 \%)$. The DNA G $+\mathrm{C}$ content of strain $\mathrm{SW}-11^{\mathrm{T}}$ was estimated as described by Mesbah et al. (1989). The nucleoside mixture was separated by HPLC. The DNA $\mathrm{G}+\mathrm{C}$ content of strain $\mathrm{SW}-11^{\mathrm{T}}$ was $51.6 \pm 1.0 \mathrm{~mol} \%$.

Biomass of SW-11 ${ }^{\mathrm{T}}$, T. turnerae ATCC $39867^{\mathrm{T}}$ and $\mathrm{S}$. degradans DSM $17024^{\mathrm{T}}$ was obtained after growing the strains in R2A medium dissolved in artificial seawater at $30{ }^{\circ} \mathrm{C}$ for 3 days. Fatty acid methyl esters were prepared, separated and identified according to the instructions of the Microbial Identification System (Microbial ID; MIDI) (Sasser, 1990). The major fatty acid constituents $(\geqslant 10 \%)$ of strain SW-11 ${ }^{\mathrm{T}}$ were summed feature $3\left(\mathrm{C}_{16: 1} \omega 7 c\right.$ and/or $\left.\mathrm{C}_{16: 1} \omega 6 c ; 22.3 \%\right), \mathrm{C}_{17: 1} \omega 8 c(13.4 \%)$, summed feature 8 $\left(\mathrm{C}_{18: 1} \omega 6 c\right.$ and/or $\left.\mathrm{C}_{18: 1} \omega 7 c ; 13.1 \%\right), \mathrm{C}_{16: 0}(10.3 \%)$ and anteiso- $\mathrm{C}_{17: 1} \omega 9 c(10.0 \%)$ (Table 1$)$. This fatty acid profile was distinct from those of T. turnerae ATCC $39867^{\mathrm{T}}$ and $S$. degradans DSM $17024^{\mathrm{T}}$. In contrast to T. turnerae ATCC $39867^{\mathrm{T}}$ and S. degradans DSM $17024^{\mathrm{T}}$, strain SW-11 ${ }^{\mathrm{T}}$ possessed fatty acids $\mathrm{C}_{17: 1} \omega 8 c$ and anteiso- $\mathrm{C}_{17: 1} \omega 9 c$. Furthermore, the quantity of fatty acid $\mathrm{C}_{16: 0}$ in strain SW $-11^{\mathrm{T}}$ was much smaller than that found in T. turnerae ATCC $39867^{\mathrm{T}}$ and S. degradans DSM $17024^{\mathrm{T}}$, while the

Table 1. Cellular fatty acid compositions of strain SW-11 ${ }^{\top}$, T. turnerae ATCC $39867^{\top}$ and S. degradans DSM $17024^{\top}$

Strains: 1 , SW- $11^{\mathrm{T}}$; 2, T. turnerae ATCC $39867^{\mathrm{T}} ; 3$, S. degradans DSM $17024^{\mathrm{T}}$. All data are from this study. Strains were grown at $30{ }^{\circ} \mathrm{C}$ for 3 days in R2A medium dissolved in artificial seawater. Values are percentages of the total fatty acids. Fatty acids that made up $<1 \%$ of the total in all three strains are not shown;,$-<1 \%$. For unsaturated fatty acids, the position of the double bond is located by counting from the methyl $(\omega)$ end of the carbon chain; cis isomers are indicated by the suffix $c$.

\begin{tabular}{|lccc|}
\hline Fatty acid & $\mathbf{1}$ & $\mathbf{2}$ & $\mathbf{3}$ \\
\hline $\mathrm{C}_{10: 0}$ & 3.5 & 3.2 & - \\
$\mathrm{C}_{10: 0} 3-\mathrm{OH}$ & 3.2 & 1.6 & 8.3 \\
$\mathrm{C}_{11: 0}$ & 2.5 & - & 2.4 \\
$\mathrm{C}_{11: 0} 3-\mathrm{OH}$ & 4.0 & - & - \\
$\mathrm{C}_{12: 0}$ & 3.0 & 2.5 & 3.0 \\
anteiso-C $\mathrm{C}_{12: 0}$ & - & - & 8.4 \\
$\mathrm{C}_{12: 0} 3-\mathrm{OH}$ & 2.4 & 4.7 & - \\
$\mathrm{C}_{12: 1} 3-\mathrm{OH}$ & - & - & 4.3 \\
anteiso-C & - & - & 4.1 \\
$\mathrm{C}_{14: 0}$ & 1.1 & 4.0 & 5.1 \\
$\mathrm{C}_{16: 0}$ & 10.3 & 20.9 & 28.9 \\
$\mathrm{C}_{17: 0}$ & 5.1 & 1.3 & 17.3 \\
$\mathrm{C}_{17: 1} \omega 6 c$ & 1.2 & - & - \\
$\mathrm{C}_{17: 1} \omega 8 c$ & 13.4 & - & - \\
anteiso-C & 10.0 & - & - \\
$\mathrm{C}_{18: 0} \omega 9 c$ & - & 4.2 & 5.1 \\
Summed feature $3 *$ & 22.3 & 18.1 & 3.4 \\
Summed feature $8^{*}$ & 13.1 & 36.7 & 9.9 \\
\hline
\end{tabular}

* Summed features are groups of two or three fatty acids that cannot be separated by GLC using the MIDI system. Summed feature 3 comprises $\mathrm{C}_{16: 1} \omega 7 c$ and/or $\mathrm{C}_{16: 1} \omega 6 c$ and summed feature 8 comprises $\mathrm{C}_{18: 1} \omega 7 c$ and/or $\mathrm{C}_{18: 1} \omega 6 c$. 
quantity of summed feature $8\left(\mathrm{C}_{18: 1} \omega 6 c\right.$ and/or $\left.\mathrm{C}_{18: 1} \omega 7 c\right)$ was much smaller than that found in T. turnerae ATCC $39867^{\mathrm{T}}$ and the quantity of summed feature $3\left(\mathrm{C}_{16: 1} \omega 7 \mathrm{c}\right.$ and/or $\left.\mathrm{C}_{16: 1} \omega 6 c\right)$ was much greater than that found in $S$. degradans DSM $17024^{\mathrm{T}}$ (Table 1).

Polar lipids were extracted and analysed by two-dimensional TLC as described by Ventosa et al. (1993). Strain SW-11 ${ }^{\mathrm{T}}, T$. turnerae ATCC $39867^{\mathrm{T}}$ and S. degradans DSM $17024^{\mathrm{T}}$ were grown in R2A broth dissolved in artificial seawater at $30{ }^{\circ} \mathrm{C}$ for 2 days. The major cellular phospholipids of strain $\mathrm{SW}-11^{\mathrm{T}}$ were phosphatidylethanolamine and phosphatidylglycerol, and the minor polar lipids were phosphatidylserine, diphosphatidylglycerol and four unknown phospholipids (PL1-PL4) (Supplementary Fig. S4). Like its closest relatives T. turnerae ATCC $39867^{\mathrm{T}}$ and S. degradans DSM $17024^{\mathrm{T}}$, strain $\mathrm{SW}-11^{\mathrm{T}}$ had phosphatidylethanolamine and phosphatidylglycerol as major cellular phospholipids. However, diphosphatidylglycerol was present in strain $\mathrm{SW}-11^{\mathrm{T}}$ and $S$. degradans DSM $17024^{\mathrm{T}}$, but absent from T. turnerae ATCC $39867^{\mathrm{T}}$. In contrast, an unknown glycolipid was present in T. turnerae ATCC $39867^{\mathrm{T}}$, but absent from strain SW-11 ${ }^{\mathrm{T}}$ and S. degradans DSM $17024^{\mathrm{T}}$. In addition, the unidentified phospholipids detected in strain $\mathrm{SW}-11^{\mathrm{T}}$ were not detected in the two reference strains. These results suggested that there are some differences in the polar lipid profiles of the three strains.

Sensitivity of strain $\mathrm{SW}-11^{\mathrm{T}}$ to antibiotics was analysed by the diffusion method on MA. Discs containing the following antibiotics (all from Oxoid; $8 \mathrm{~mm}$ diameter) were used: ampicillin $(10 \mu \mathrm{g})$, chloramphenicol $(30 \mu \mathrm{g})$, gentamicin $(10 \mu \mathrm{g})$, kanamycin $(30 \mu \mathrm{g})$, nalidixic acid $(30 \mu \mathrm{g})$, novobiocin $(30 \mu \mathrm{g})$, rifampicin $(5 \mu \mathrm{g})$, penicillin $\mathrm{G}(10 \mathrm{U})$, streptomycin $(10 \mu \mathrm{g})$ and tetracycline $(30 \mu \mathrm{g})$. The effects of antibiotics on cell growth were assessed after 3 days of incubation at $30{ }^{\circ} \mathrm{C}$. The strain was considered susceptible when the diameter of the inhibition zone was $>13 \mathrm{~mm}$, intermediate at $10-12 \mathrm{~mm}$ and resistant at $<10 \mathrm{~mm}$, as described by Nokhal \& Schlegel (1983).

Detailed results of phenotypic and chemotaxonomic characterization are given in the genus and species descriptions and in Tables 1 and 2. Several phenotypic and chemotaxonomic characteristics can be used to differentiate strain $\mathrm{SW}-11^{\mathrm{T}}$ from the related genera Teredinibacter and Saccharophagus. Strain $\mathrm{SW}-11^{\mathrm{T}}$ can be differentiated from $T$. turnerae ATCC $39867^{\mathrm{T}}$ by the presence of $\mathrm{C}_{17: 1} \omega 8 c$ and anteiso- $\mathrm{C}_{17: 1} \omega 9 c$ (Table 1) and the absence of glycolipid and aminolipids and the presence of diphosphatidylglycerol and several additional phospholipids (Supplementary Fig. S4). Strain $\mathrm{SW}-11^{\mathrm{T}}$ is also distinguished from T. turnerae ATCC $39867^{\mathrm{T}}$ by its colony pigmentation, the ability to grow on Difco MA, the inability to grow at lower $\mathrm{NaCl}$ concentrations, its ability to produce indole and to hydrolyse gelatin, corn oil, lecithin and starch, the presence of C14 lipase and cystine arylamidase, the absence of $\alpha$-galactosidase and $\beta$-galactosidase and the utilization of D-mannose and propionic acid as carbon and energy sources. Phenotypic and chemotaxonomic characteristics such as the presence of $\mathrm{C}_{17: 1} \omega 8 c$ and anteiso- $\mathrm{C}_{17: 1} \omega 9 c$ (Table 1), the absence of aminolipids and the presence of several additional phospholipids (Supplementary Fig. S4), the smaller cell size, the lower $\mathrm{NaCl}$ range for growth, the inability to grow at $4{ }^{\circ} \mathrm{C}$, the ability to produce indole, the absence of eumelanin production, the presence of $\mathrm{C} 14$ lipase, valine arylamidase, cystine arylamidase, trypsin, $\alpha$-chymotrypsin and acid phosphatase, the inability to hydrolyse agar, alginate, chitin or CM-cellulose, the ability to hydrolyse gelatin, corn oil, lecithin and Tweens 40 and 80 and the utilization of D-mannose, acetic acid, propionic acid and succinic acid as carbon and energy sources (Table 2) may be helpful in differentiating strain $\mathrm{SW}-11^{\mathrm{T}}$ from $S$. degradans DSM $17024^{\mathrm{T}}$.

Strain SW- $11^{\mathrm{T}}$ shares $93.2 \%$ 16S rRNA gene sequence similarity with $T$. turnerae $\mathrm{T} 7902^{\mathrm{T}}$ and $92.1 \%$ with $S$. degradans $2-40^{\mathrm{T}}$. The suggested lower cut-off of $95 \% 16 \mathrm{~S}$ rRNA gene sequence similarity for genera (Yarza et al., 2008; Tindall et al., 2010) seems reasonable, and there are several differential phenotypic and chemotaxonomic characteristics between the novel strain and these two related genera. From the results of 16S rRNA gene sequencing, it appears that strain $\mathrm{SW}-11^{\mathrm{T}}$ is distinct from any other genera in the order Alteromonadales. Consequently, on the basis of a combination of genotypic and phenotypic differences among strain SW- $11^{\mathrm{T}}$, T. turnerae ATCC $39867^{\mathrm{T}}$ and S. degradans DSM $17024^{\mathrm{T}}$, we suggest that strain $\mathrm{SW}-11^{\mathrm{T}}$ represents a new genus and species in the order Alteromonadales, for which the name Pseudoteredinibacter isoporae gen. nov., sp. nov. is proposed.

\section{Description of Pseudoteredinibacter gen. nov.}

Pseudoteredinibacter (Pseu'do.te.re.di'ni.bac'ter. Gr. adj. pseudes false; N.L. masc. n. Teredinibacter a bacterial generic name; N.L. masc. n. Pseudoteredinibacter false Teredinibacter).

Cells are Gram-negative, chemoheterotrophic, motile, aerobic rods. The predominant fatty acids are summed feature $3\left(\mathrm{C}_{16: 1} \omega 7 c\right.$ and/or $\left.\mathrm{C}_{16: 1} \omega 6 c\right), \mathrm{C}_{17: 1} \omega 8 c$, summed feature $8\left(\mathrm{C}_{18: 1} \omega 6 c\right.$ and/or $\left.\mathrm{C}_{18: 1} \omega 7 c\right), \mathrm{C}_{16: 0}$ and anteiso$\mathrm{C}_{17: 1} \omega 9 c$. The major polar lipids are phosphatidylethanolamine and phosphatidylglycerol. The major respiratory quinones are Q-9 and Q-8. The DNA G + C content of the type strain of the type species is $51.6 \mathrm{~mol} \%$. The type species is Pseudoteredinibacter isoporae.

\section{Description of Pseudoteredinibacter isoporae sp. nov.}

Pseudoteredinibacter isoporae (N.L. n. Isopora the scientific name of a genus of coral; N.L. gen. n. isoporae of Isopora, referring to the isolation of the type strain from a coral belonging to the genus Isopora).

Displays the following properties in addition to those described for the genus. Cells are motile by a single polar 
Table 2. Differential characteristics of strain SW $-11^{\top}$, T. turnerae ATCC $39867^{\top}$ and S. degradans DSM $17024^{\top}$

Strains: 1 , P. isoporae SW $-11^{\mathrm{T}}$; 2, T. turnerae ATCC $39867^{\mathrm{T}} ; 3$, S. degradans DSM $17024^{\mathrm{T}}$. Data were acquired in this study except for the DNA $\mathrm{G}+\mathrm{C}$ contents of T. turnerae (range of values for six isolates from Distel et al., 2002) and S. degradans DSM 17024 (data from Ekborg et al., 2005). + , Positive; -, negative; w, weakly positive. All strains are Gram-negative and oxidase- and catalase-positive.

\begin{tabular}{|c|c|c|c|}
\hline Characteristic & 1 & 2 & 3 \\
\hline Colony colour & Colourless, semi-translucent & Yellow-brown & Cream \\
\hline Cell shape & Rods & Pleomorphic rods & Pleomorphic rods \\
\hline Growth on MA (Difco) & + & - & + \\
\hline $\mathrm{NaCl}$ range for growth $(\%, w / v)$ & $2-4$ & $0.5-4$ & $1-10$ \\
\hline $\mathrm{pH}$ range for growth & $7-8$ & $6-10.5$ & $4.5-10$ \\
\hline Indole production & + & - & - \\
\hline Eumelanin production & - & - & + \\
\hline \multicolumn{4}{|l|}{ Enzyme activities (API ZYM) } \\
\hline C14 lipase & + & - & - \\
\hline Valine arylamidase & + & + & - \\
\hline Cystine arylamidase & + & - & - \\
\hline$\beta$-Galactosidase & - & + & - \\
\hline \multicolumn{4}{|l|}{ Hydrolysis of: } \\
\hline Agar & - & - & + \\
\hline Alginate & - & - & + \\
\hline Chitin & - & - & + \\
\hline CM-cellulose & - & + & + \\
\hline Starch & $\mathrm{w}$ & - & + \\
\hline Gelatin & + & - & - \\
\hline Corn oil & + & - & - \\
\hline Lecithin & + & - & - \\
\hline Tweens 40 and 80 & + & + & - \\
\hline Major fatty acids $(\geqslant 9.9 \%)^{*}$ & $\begin{array}{c}\mathrm{SF} 3, \mathrm{C}_{17: 1} \omega 8 c, \mathrm{SF} 8, \mathrm{C}_{16: 0} \\
\text { ai- } \mathrm{C}_{17: 1} \omega 9 c\end{array}$ & $\mathrm{SF} 8, \mathrm{C}_{16: 0}, \mathrm{SF} 3$ & $\mathrm{C}_{16: 0}, \mathrm{C}_{17: 0}, \mathrm{SF} 8$ \\
\hline Polar lipids $\dagger$ & PE, PG, PS, DPG, PL1-4 & PE, PG, PS, GL, AL1-2, PL5 & PE, PG, PS, DPG, AL3, PL6-9 \\
\hline Isolation source & Coral & Endosymbiont of teredinid bivalve & Salt marsh \\
\hline DNA G $+C$ content $(\mathrm{mol} \%)$ & 51.6 & $49-51$ & 45.8 \\
\hline
\end{tabular}

*ai, Anteiso-branched; SF3, summed feature $3\left(\mathrm{C}_{16: 1} \omega 7 c\right.$ and/or $\left.\mathrm{C}_{16: 1} \omega 6 c\right)$; SF8, summed feature $8\left(\mathrm{C}_{18: 1} \omega 6 c\right.$ and/or $\left.\mathrm{C}_{18: 1} \omega 7 c\right)$. $\nmid D P G$, Diphosphatidylglycerol; PE, phosphatidylethanolamine; PG, phosphatidylglycerol; PS, phosphatidylserine; AL1-3, unknown aminolipids; GL, unknown glycolipid; PL1-9, unknown phospholipids.

flagellum. After $48 \mathrm{~h}$ growth on MA at $30{ }^{\circ} \mathrm{C}$, mean cell size is $0.3-0.4 \times 0.7-1.2 \mu \mathrm{m}$. Colonies are round, entire, convex, colourless and semi-translucent, approximately $0.8-1.0 \mathrm{~mm}$ in diameter on MA after $48 \mathrm{~h}$ incubation at $30{ }^{\circ} \mathrm{C}$. Grows at 10-45 ${ }^{\circ} \mathrm{C}$ (optimum, 30-35 ${ }^{\circ} \mathrm{C}$ ), at $\mathrm{pH}$ 7.0-8.0 (optimum, $\mathrm{pH} 7.5)$ and with $2.0-4.0 \%(\mathrm{w} / \mathrm{v}) \mathrm{NaCl}$ (optimum, $2.5-3.0 \%)$. Eumelanin production is not observed. No accumulation of poly- $\beta$-hydroxybutyrate granules. Positive for oxidase, catalase, DNase, lipase (corn oil) and hydrolysis of starch, gelatin, aesculin, lecithin and Tweens 20, 40, 60 and 80 . Negative for hydrolysis of agar, alginate, chitin, CMcellulose and casein. In API 20NE tests, negative for glucose acidification, arginine dihydrolase and urease and assimilation of glucose, mannose, malate, arabinose, mannitol, 
gluconate, caprate, adipate, citrate and phenylacetate; positive for nitrate and nitrite reduction, indole production, $\beta$-glucosidase, protease and assimilation of $\mathrm{N}$-acetylglucosamine and maltose. In the API ZYM system, alkaline phosphatase, C4 esterase, C8 esterase lipase, C14 lipase, leucine arylamidase, valine arylamidase, cystine arylamidase, trypsin, $\alpha$-chymotrypsin, acid phosphatase and naphtholAS-BI-phosphohydrolase activities are present, and $\alpha$ galactosidase, $\beta$-galactosidase, $\beta$-glucuronidase, $\alpha$-glucosidase, $\beta$-glucosidase, $N$-acetyl- $\beta$-glucosaminidase, $\alpha$-mannosidase and $\alpha$-fucosidase activities are absent. The following compounds are oxidized in the Biolog GN2 MicroPlate: Tweens 40 and 80, D-arabitol, cellobiose, $\alpha$-D-glucose, D-mannose, acetic acid, $\beta$-hydroxybutyric acid, $\gamma$-hydroxybutyric acid, $\alpha$ ketoglutaric acid, propionic acid, quinic acid, D-saccharic acid, succinic acid, bromosuccinic acid, succinamic acid, glucuronamide, L-alaninamide, D- and L-alanine, L-alanyl glycine, L-asparagine, L-aspartic acid, L-glutamic acid, glycyl L-aspartic acid, glycyl L-glutamic acid, L-histidine, hydroxyL-proline, L-leucine, L-ornithine, L-phenylalanine, L-proline, L-pyroglutamic acid, D- and L-serine, L-threonine, DL-carnitine, $\gamma$-aminobutyric acid, urocanic acid, inosine, uridine, thymidine, phenylethylamine, putrescine, 2-aminoethanol, 2,3-butanediol, glycerol, DL- $\alpha$-glycerol phosphate, $\alpha$-D-glucose 1-phosphate and D-glucose 6-phosphate. All other substrates in the GN2 microplate are not oxidized. Utilizes the following compounds as carbon and energy sources: cellobiose, aesculin, D-glucose, D-mannose, acetate, propionate, succinate, glycerol, L-alanine, L-arginine, L-asparagine, L-aspartate, L-glycine, L-glutamic acid, L-histidine, L-leucine, L-lysine, L-phenylalanine, L-proline, L-serine, L-threonine, L-valine and urea. The following compounds are not used as carbon and energy sources: amygdalin, L-arabinose, D-fructose, D-galactose, lactose, maltotriose, maltose, D-ribose, D-salicin, trehalose, xylose, sucrose, citrate, gluconate, lactate, malate, malonate, pyruvate, adonitol, myo-inositol, D-mannitol, L-cysteine, L-isoleucine, L-methionine and L-tryptophan. The type strain is sensitive to discs containing rifampicin $(5 \mu \mathrm{g})$, kanamycin $(30 \mu \mathrm{g})$, nalidixic acid $(360 \mu \mathrm{g})$, chloramphenicol $(30 \mu \mathrm{g})$, gentamicin $(10 \mu \mathrm{g})$, novobiocin $(30 \mu \mathrm{g})$, tetracycline $(30 \mu \mathrm{g})$, streptomycin $(10 \mu \mathrm{g})$ and penicillin $(10 \mathrm{U})$ but is resistant to ampicillin $(10 \mu \mathrm{g})$. Minor polar lipids include phosphatidylserine, diphosphatidylglycerol and four unknown phospholipids.

The type strain, SW $-11^{\mathrm{T}}\left(=\right.$ BCRC $\left.17935^{\mathrm{T}}=\mathrm{LMG} 25246^{\mathrm{T}}\right)$, was isolated from the coral Isopora palifera.

\section{Acknowledgements}

This study was funded by grants from the Academia Sinica (Thematic Grant 20082010), Taipei, Taiwan, Republic of China.

\section{References}

Bowman, J. P. (2000). Description of Cellulophaga algicola sp. nov., isolated from the surfaces of Antarctic algae, and reclassification of Cytophaga uliginosa (ZoBell and Upham 1944) Reichenbach 1989 as Cellulophaga uliginosa comb. nov. Int J Syst Evol Microbiol 50, 1861-1868.
Brown, B. E. \& Bythell, J. C. (2005). Perspectives on mucus secretion in reef corals. Mar Ecol Prog Ser 296, 291-309.

Chen, W. M., Laevens, S., Lee, T. M., Coenye, T., De Vos, P., Mergeay, M. \& Vandamme, P. (2001). Ralstonia taiwanensis sp. nov., isolated from root nodules of Mimosa species and sputum of a cystic fibrosis patient. Int J Syst Evol Microbiol 51, 1729-1735.

Chiou, S. F., Kuo, J., Wong, T. Y., Fan, T. Y., Tew, K. S. \& Liu, J. K. (2010). Analysis of the coral associated bacterial community structures in healthy and diseased corals from off-shore of southern Taiwan. J Environ Sci Health B 45, 408-415.

Choi, D. H., Kim, Y.-G., Hwang, C. Y., Yi, H., Chun, J. \& Cho, B. C. (2006). Tenacibaculum litoreum sp. nov., isolated from tidal flat sediment. Int J Syst Evol Microbiol 56, 635-640.

Collins, M. D. (1985). Analysis of isoprenoid quinones. Methods Microbiol 18, 329-366.

Distel, D. L., Morrill, W., MacLaren-Toussaint, N., Franks, D. \& Waterbury, J. (2002). Teredinibacter turnerae gen. nov., sp. nov., a dinitrogen-fixing, cellulolytic, endosymbiotic $\gamma$-proteobacterium isolated from the gills of wood-boring molluscs (Bivalvia: Teredinidae). Int J Syst Evol Microbiol 52, 2261-2269.

Ekborg, N. A., Gonzalez, J. M., Howard, M. B., Taylor, L. E., Hutcheson, S. W. \& Weiner, R. M. (2005). Saccharophagus degradans gen. nov., sp. nov., a versatile marine degrader of complex polysaccharides. Int J Syst Evol Microbiol 55, 1545-1549.

Felsenstein, J. (1981). Evolutionary trees from DNA sequences: a maximum likelihood approach. J Mol Evol 17, 368-376.

Gerhardt, P., Murray, R. G. E., Wood, W. A. \& Krieg, N. R. (editors) (1994). Methods for General and Molecular Bacteriology. Washington, DC: American Society for Microbiology.

Hall, T. A. (1999). BioEdit: a user-friendly biological sequence alignment editor and analysis program for Windows 95/98/NT. Nucleic Acids Symp Ser 41, 95-98.

Hong, M. J., Yu, Y. T., Chen, C. A., Chiang, P. W. \& Tang, S. L. (2009). Influence of species specificity and other factors on bacteria associated with the coral Stylophora pistillata in Taiwan. Appl Environ Microbiol 75, 7797-7806.

Hosoya, S., Adachi, K. \& Kasai, H. (2009). Thalassomonas actiniarum sp. nov. and Thalassomonas haliotis sp. nov., isolated from marine animals. Int J Syst Evol Microbiol 59, 686-690.

Hsu, S. C. \& Lockwood, J. L. (1975). Powdered chitin agar as a selective medium for enumeration of actinomycetes in water and soil. Appl Microbiol 29, 422-426.

Kelly, S. K., Coyne, V. E., Sledjeski, D. D., Fuqua, W. C. \& Weiner, R. M. (1990). Identification of a tyrosinase from a periphytic marine bacterium. FEMS Microbiol Lett 67, 275-279.

Kimura, M. (1983). The Neutral Theory of Molecular Evolution. Cambridge: Cambridge University Press.

Kluge, A. G. \& Farris, F. S. (1969). Quantitative phyletics and the evolution of anurans. Syst Zool 18, 1-12.

Kumar, S., Tamura, K. \& Nei, M. (2004). MEGA3: integrated software for molecular evolutionary genetics analysis and sequence alignment. Brief Bioinform 5, 150-163.

Kvennefors, E. C. E., Sampayo, E., Ridgway, T., Barnes, A. C. \& Hoegh-Guldberg, O. (2010). Bacterial communities of two ubiquitous Great Barrier Reef corals reveals both site- and species-specificity of common bacterial associates. PLOS ONE 5, e10401.

Lyman, J. \& Fleming, R. H. (1940). Composition of sea water. J Mar Res 3, 134-146.

Mesbah, M., Premachandran, U. \& Whitman, W. B. (1989). Precise measurement of the $\mathrm{G}+\mathrm{C}$ content of deoxyribonucleic acid by highperformance liquid chromatography. Int J Syst Bacteriol 39, 159-167. 
Miller, P. H., Wiggs, L. S. \& Miller, J. M. (1995). Evaluation of AnaeroGen system for growth of anaerobic bacteria. J Clin Microbiol 33, 2388-2391.

Minnikin, D. E., O'Donnell, A. G., Goodfellow, M., Alderson, G., Athalye, M., Schaal, K. \& Parlett, J. H. (1984). An integrated procedure for the extraction of bacterial isoprenoid quinones and polar lipids. J Microbiol Methods 2, 233-241.

Monreal, J. \& Reese, E. T. (1969). The chitinase of Serratia marcescens. Can J Microbiol 15, 689-696.

Nokhal, T.-H. \& Schlegel, H. G. (1983). Taxonomic study of Paracoccus denitrificans. Int J Syst Bacteriol 33, 26-37.

Powers, E. M. (1995). Efficacy of the Ryu nonstaining $\mathrm{KOH}$ technique for rapidly determining gram reactions of food-borne and waterborne bacteria and yeasts. Appl Environ Microbiol 61, 3756-3758.

Rosenberg, E., Koren, O., Reshef, L., Efrony, R. \& Zilber-Rosenberg, I. (2007). The role of microorganisms in coral health, disease and evolution. Nat Rev Microbiol 5, 355-362.

Rypien, K. L., Ward, J. R. \& Azam, F. (2010). Antagonistic interactions among coral-associated bacteria. Environ Microbiol 12, 28-39.

Saitou, N. \& Nei, M. (1987). The neighbor-joining method: a new method for reconstructing phylogenetic trees. Mol Biol Evol 4, 406-425.

Sampayo, E. M., Ridgway, T., Bongaerts, P. \& Hoegh-Guldberg, O. (2008). Bleaching susceptibility and mortality of corals are determined by fine-scale differences in symbiont type. Proc Natl Acad Sci U S A 105, 10444-10449.
Sasser, M. (1990). Identification of bacteria by gas chromatography of cellular fatty acids, MIDI Technical Note 101. Newark, DE: MIDI, Inc.

Smibert, R. M. \& Krieg, N. R. (1994). Phenotypic characterization. In Methods for General and Molecular Bacteriology, pp. 607-654. Edited by P. Gerhardt, R. G. E. Murray, W. A. Wood \& N. R. Krieg. Washington, DC: American Society for Microbiology.

Thompson, J. D., Gibson, T. J., Plewniak, F., Jeanmougin, F. \& Higgins, D. G. (1997). The CLUSTAL_X windows interface: flexible strategies for multiple sequence alignment aided by quality analysis tools. Nucleic Acids Res 25, 4876-4882.

Tindall, B. J., Rosselló-Móra, R., Busse, H.-J., Ludwig, W. \& Kämpfer, P. (2010). Notes on the characterization of prokaryote strains for taxonomic purposes. Int J Syst Evol Microbiol 60, 249-266.

Ventosa, A., Marquez, M. C., Kocur, M. \& Tindall, B. J. (1993). Comparative study of "Micrococcus sp." strains CCM 168 and CCM 1405 and members of the genus Salinicoccus. Int J Syst Bacteriol 43, 245-248.

Waterbury, J. B., Calloway, C. B. \& Turner, R. D. (1983). A cellulolytic nitrogen-fixing bacterium cultured from the gland of Deshayes in shipworms (Bivalvia: Teredinidae). Science 221, 1401-1403.

Yarza, P., Richter, M., Peplies, J., Euzéby, J., Amann, R., Schleifer, K. H., Ludwig, W., Glöckner, F. O. \& Rosselló-Móra, R. (2008). The All-Species Living Tree project: a $16 \mathrm{~S}$ rRNA-based phylogenetic tree of all sequenced type strains. Syst Appl Microbiol 31, 241-250. 